ISSN 1392-3196 / e-ISSN 2335-8947

Zemdirbyste-Agriculture, vol. 101, No. 2 (2014), p. 215-220

DOI 10.13080/z-a.2014.101.028

\title{
The evaluation of anthocyanin content of honeyberry (Lonicera kamtschatica) clones during freezing in relation to antioxidant activity and parameters of nutritional value
} \author{
Luba ĎURIŠOVÁ ${ }^{6}$ \\ Constantine the Philosopher University \\ Drazovska 4, Nitra, Slovakia \\ ${ }^{2}$ Atatürk University \\ 25240 Erzurum, Turkey \\ E-mail: sercisli@gmail.com \\ ${ }^{3}$ College of Business and Hotel Management \\ Bosonožská 9, 62500 Brno, Czech Republic \\ ${ }^{4}$ Tomas Bata University \\ Namesti TGM 275, Zlin, Czech Republic \\ ${ }^{5}$ Mendel University \\ Valtická 337, 69144 Lednice, Brno, Czech Republic \\ ${ }^{6}$ Slovak Agriculture University \\ Nitra, Slovakia \\ ${ }^{7}$ Plant Production Research Center \\ Bratislavska cesta 122, 92168 Piestany, Slovakia
}

Tunde JURIKOVA ${ }^{1}$, Sezai ERCIŞLI ${ }^{2}$, Otakar ROP ${ }^{3}$, Jiri MLCEK ${ }^{4}$, Stefan BALLA ${ }^{1}$, Rastislav ZITNY ${ }^{1}$, Jiri SOCHOR ${ }^{5}$, Alzbeta HEGEDUSOVA ${ }^{6}$, Daniela BENEDIKOVA ${ }^{7}$,

${ }^{1}$ Institute for Teacher Training, Faculty of Central European Studies,

\begin{abstract}
The aim of the study was to determine changes in anthocyanin content of 17 selected Klčov's clones of honeyberry (Lonicera kamtschatica (Sevast.) Pojark) during freezing at $-18^{\circ} \mathrm{C}$ for 6 months and find out the relationship between anthocyanins and dry matter, sugar, organic acids and ascorbic acid content in fresh fruits by cluster analysis. Clones of honeyberry can be divided into three clusters according to dry matter, sugar, organic acids and total anthocyanin content and total antioxidant capacity. The total anthocyanin level measured in fresh samples was 5.96-19.80 mg $100 \mathrm{~g}^{-1}$ of fresh mass (FM). The scavenging effect of acidified $80 \%$ ethanol extracts on DPPH (1,1-diphenyl-2-picrylhydrazyl) radical ranged from $30.03 \%$ to $41.13 \%$. Anthocyanins displayed a negative weak correlation with total antioxidant capacity $(R=-0.585)$.
\end{abstract}

Key words: anthocyanin, antioxidant activity, ascorbic acid, dry matter, freezing, Lonicera kamtschatica.

\section{Introduction}

Less common fruit species particularly berries are considered to provide the fruit with a high biological value (Ercisli, Esitken, 2004; Kafkas et al., 2008; Beslic et al., 2010; Milivojevic et al., 2011; Poledica et al., 2012). One of the possibilities how to express the biological value of foodstuff is the determination of antioxidant capacity, concurrently with the assessment of mainly presented bioactive components in berries (Gazdik et al., 2008). The honeyberries represent a lesser-known berry crop originated from the territory of Russia, rich in antioxidants; with a high content of ascorbic acid and polyphenolic compounds - phenolic acids and flavonoids. Among flavonoids proanthocyanins, anthocyanins, quercetin, isoquercetin and rutin are predominant. At the same time, anthocyanins represented the group of flavonoids which mostly contributed to antioxidant activity of honeyberry fruit as this has been confirmed by the studies of Chaovanalikit et al. (2004) and Gazdik et al. (2008).

Nowadays, polyphenolics especially an anthocyanin extract from honeyberry have been very effective in the prevention of chronic diseases such as 
cancer (Gruia et al., 2008), neurodegenerative diseases (Gazdik et al., 2008), their anti-inflammatory effect has been proved as well (Svobodova et al., 2009). The colour stability of anthocyanin depends on the combination of various factors such as the structure and concentration of anthocyanin, $\mathrm{pH}$, temperature and presence of complexing agents (phenols, metals) or other chemical substances (Jurikova et al., 2012). The content of anthocyanins in honeyberry fruit is influenced by way of extraction procedure, organic acids and ascorbic acid content (Myjavcova et al., 2010). Therefore, it is necessary to find a way of the sample preservation without a loss in anthocyanins and evaluate the relation between anthocyanins and mentioned parameters of nutritional value of fruits. Freezing at $-18^{\circ} \mathrm{C}$ has been recommended as the most effective way of fruit storage for berry crop generally (Baloghova et al., 2009) and for honeyberries as well (Jurikova et al., 2012).

The aim of our study was to monitor the contents of dry matter, sugar, organic and ascorbic acid in relation to total anthocyanin content depending on particular Klčov's clones of Lonicera kamtschatica fruit. Moreover, the same fruit was measured for the content of anthocyanins and total antioxidant capacity after six months of freezing at $-18^{\circ} \mathrm{C}$.

\section{Material and methods}

Sample collection and the preparation for chemical analyses. The samples of selected 17 clones of honeyberry (Lonicera kamtschatica (Sevast.) Pojark) were taken from experimental orchards of Slovak Agriculture University in Nitra in June 2011. The locality is characterised by $130 \mathrm{~m}$ above sea level. During the vegetation period, the average precipitation was $364 \mathrm{~mm}$ and the average temperature was $16.3^{\circ} \mathrm{C}$. The samples were manually collected from five shrubs per clone. The representative sample was $100 \mathrm{~g}$ from five plants -500 $\mathrm{g}$ together represented in replications of experiment. The average sample was obtained by dividing into quarters. Fifty grams of fresh samples of selected clones of honeyberry were immediately processed after collecting while frozen samples $(50 \mathrm{~g})$ were kept in polyethylene bags for up to six months at $-18^{\circ} \mathrm{C}$. Fresh samples of fruits were used for determination of anthocyanins. In frozen samples, the content of total anthocyanins (TA) and total antioxidant capacity (TAC) of fruit was examined. For determination of TA content the samples were homogenized and extracted by $100 \mathrm{ml}$ of acidified $80 \%$ ethanol for 12 hours at $25^{\circ} \mathrm{C}$. In obtained extracts TA content was measured spectrophotometrically by the method of Füleki and Francis (1968) and expressed as cyanidin-3-glucoside equivalent. Because the content of anthocyanin is influenced by other parameters of nutritional value of fruit, it was related to dry matter, organic acids, sugars and ascorbic acid content. The parameters of nutritional value were determined in fresh fruits.

In order to find out the content of dry matter, berries were dried until reaching the constant weight. Organic acids were determined by the $\mathrm{NaOH}$ titration on the methylene blue indicator and were calculated as citric acid (g $100 \mathrm{~g}^{-1}$ of fresh mass (FM). The content of sugar was determined by the method of Somogyi. The amount of ascorbic acid was obtained by polarography. The TAC of frozen samples was measured by the DPPH (1,1-diphenyl-2-picrylhydrazyl) method of Parejo et al. (2000). Spectrophotometric measurements of antioxidant activity were carried out using an automated chemical analyser BS-400 ("Mindray", China). It is composed of cuvette space tempered to $37 \pm 1{ }^{\circ} \mathrm{C}$, reagent space with a carousel for reagents (tempered to $4 \pm 1^{\circ} \mathrm{C}$ ), sample space with a carousel for preparation of samples and an optical detector. Transfer of samples and reagents is provided by robotic arm equipped with a dosing needle (error of dosage up to $5 \%$ of volume). Cuvette contents are mixed by an automatic mixer including a stirrer immediately after addition of reagents or samples.

Statistical analysis. To evaluate the influence of freezing on anthocyanins, differences among clones in anthocyanin content, the obtained results were statistically evaluated by $A N O V A$ single factor analysis $(\alpha=0.05)$. The content of anthocyanin, dry matter, sugar, organic acids, and C-vitamin (ascorbic acid) was determined. We were trying to find the relationship between anthocyanin and other components in various clones of honeyberry. First of all, we determined clusters of relative clones and secondly, we found significant clones and characterised them in principal component classification. We used cluster analysis with Euclidian distances and mean distribution. Variables were anthocyanins, dry matter, organic acids, sugar and ascorbic acid. According to principal component classification method, firstly we determined the highest variability according to Eigen values from Table. Then we determined factor and variable correlation from 2-D plot. Finally we determined factor coordinates of the cases with regard of variables and drove plot of factor coordinates of cases in 2-D plot. Correlations between TA and TAC, organic acids and ascorbic acid content were provided in program Statistica.

\section{Results}

The content of TA found in fresh samples was very variable from $5.96 \mathrm{mg} \mathrm{kg}^{-1}$ (LKL-103) up to $19.18 \mathrm{gkg}^{-1}$ (LKL-18) and clone-dependent as it was proved by $A N O V A$ single factor analysis $(P=0.006)$ at probability level $\alpha=0.05$. Among the assayed clones we determined an increase or a decrease in TA content during storage by freezing. Because of significant decline in TA content during freezing storage in LKL-18 and LKL-19, they cannot be recommended for long term storage. On the other hand, they showed the highest values of TA in fresh fruit so they can be utilised for direct consumption. Although we found out significant changes in LKL-18 and LKL-19 after freezing process, frozen samples did not show a statistically significant changes in anthocyanin levels during six months' storage $(P=0.043)$ at probability level $\alpha=0.05$. The highest value of TAC in frozen samples was measured in LKL-103 (41.3\%) representing the clone 
with the lowest value of TA. Anthocyanins displayed a weak negative correlation with TAC $(R=-0.585)$. In the second part of our experiment we classified clones according to TA content in relation to dry matter, sugars, organic acids and ascorbic acid content in fresh fruits.
A positive correlation was determined between TA and organic acids content $(R=0.48)$, TA and ascorbic acid content $(R=0.34)$ at probability level $\alpha=0.05$. It is important for further utilisation of fruit in food processing as natural dyes. The results are given in Table.

Table. The total anthocyanin content ( $\mathrm{g} \mathrm{kg}^{-1}$ of fresh mass (FM) and freezing mass), total antioxidant capacity (\% of inhibition), content of dry matter (\% w/v), content of sugars (g $100 \mathrm{~g}^{-1}$ of FM), content of organic acids (g $100 \mathrm{~g}^{-1}$ of $\mathrm{FM})$ and ascorbic acid content (mg $100 \mathrm{~g}^{-1}$ of FM)

\begin{tabular}{cccccccc}
\hline Clones & $\begin{array}{c}\text { Anthocyanins } \\
\text { before freezing }\end{array}$ & $\begin{array}{c}\text { Anthocyanins } \\
\text { after freezing }\end{array}$ & $\begin{array}{c}\text { Total } \\
\text { antioxidant } \\
\text { capacity }\end{array}$ & Dry matter & Sugars & $\begin{array}{c}\text { Organic } \\
\text { acids }\end{array}$ & Ascorbic acid \\
\hline LKL-2 & $12.88 \pm 1.08$ & $14.12 \pm 2.98$ & $30.90 \pm 3.98$ & $17.89 \pm 1.45$ & $3.70 \pm 0.45$ & $2.32 \pm 0.05$ & $24.62 \pm 2.65$ \\
LKL-3 & $8.08 \pm 0.75$ & $6.11 \pm 0.54$ & $31.60 \pm 2.98$ & $16.96 \pm 2.45$ & $6.70 \pm 0.54$ & $2.17 \pm 0.08$ & $35.66 \pm 3.45$ \\
LKL-5 & $12.03 \pm 2.02$ & $15.00 \pm 2.85$ & $33.80 \pm 4.52$ & $17.54 \pm 3.04$ & $3.30 \pm 0.89$ & $2.62 \pm 0.04$ & $28.17 \pm 1.89$ \\
LKL-6 & $8.06 \pm 0.56$ & $8.81 \pm 0.75$ & $37.80 \pm 5.54$ & $17.03 \pm 3.48$ & $4.40 \pm 0.65$ & $1.69 \pm 0.04$ & $12.94 \pm 0.78$ \\
LKL-7 & $7.46 \pm 0.52$ & $6.45 \pm 0.35$ & $32.70 \pm 2.74$ & $17.26 \pm 4.12$ & $3.90 \pm 1.02$ & $2.24 \pm 0.05$ & $9.71 \pm 0.06$ \\
LKL-14 & $11.74 \pm 2.08$ & $13.15 \pm 4.52$ & $33.80 \pm 2.01$ & $17.23 \pm 2.48$ & $4.40 \pm 0.05$ & $2.60 \pm 0.70$ & $15.43 \pm 1.78$ \\
LKL-15 & $10.75 \pm 1.98$ & $10.55 \pm 0.65$ & $33.10 \pm 1.89$ & $17.03 \pm 3.45$ & $5.00 \pm 2.14$ & $2.33 \pm 0.45$ & $34.02 \pm 2.06$ \\
LKL-16 & $7.38 \pm 0.44$ & $5.26 \pm 0.42$ & $33.50 \pm 1.56$ & $15.67 \pm 2.78$ & $3.30 \pm 0.65$ & $1.52 \pm 0.02$ & $24.12 \pm 1.89$ \\
LKL-18 & $14.36 \pm 1.80$ & $7.85 \pm 0.08$ & $30.03 \pm 1.20$ & $17.33 \pm 3.11$ & $9.50 \pm 1.78$ & $2.00 \pm 0.01$ & $39.91 \pm 1.78$ \\
LKL-19 & $19.18 \pm 2.50$ & $11.16 \pm 2.07$ & $32.90 \pm 2.54$ & $17.54 \pm 4.41$ & $5.00 \pm 0.78$ & $2.38 \pm 0.18$ & $18.31 \pm 0.58$ \\
LKL-20 & $12.05 \pm 1.85$ & $7.01 \pm 0.22$ & $31.69 \pm 3.45$ & $14.15 \pm 2.56$ & $7.20 \pm 0.56$ & $1.63 \pm 0.05$ & $32.09 \pm 1.65$ \\
LKL-21 & $13.51 \pm 2.06$ & $9.26 \pm 0.54$ & $30.90 \pm 2.74$ & $15.57 \pm 1.78$ & $6.60 \pm 0.44$ & $2.08 \pm 0.08$ & $10.34 \pm 0.45$ \\
LKL-31 & $14.53 \pm 1.89$ & $10.22 \pm 0.23$ & $33.40 \pm 3.05$ & $18.24 \pm 2.87$ & $9.00 \pm 2.07$ & $2.24 \pm 0.12$ & $46.67 \pm 4.08$ \\
LKL-35 & $12.16 \pm 1.74$ & $9.60 \pm 0.33$ & $32.00 \pm 1.74$ & $16.54 \pm 2.25$ & $8.50 \pm 0.89$ & $2.59 \pm 1.01$ & $20.81 \pm 0.89$ \\
LKL-96 & $7.98 \pm 0.45$ & $6.33 \pm 0.48$ & $35.00 \pm 4.05$ & $15.95 \pm 2.20$ & $7.20 \pm 0.45$ & $1.54 \pm 0.08$ & $17.81 \pm 0.58$ \\
LKL-102 & $7.73 \pm 0.66$ & $6.36 \pm 0.24$ & $32.19 \pm 2.74$ & $17.75 \pm 3.45$ & $7.80 \pm 0.56$ & $1.63 \pm 0.09$ & $13.63 \pm 1.44$ \\
LKL-103 & $5.96 \pm 0.32$ & $4.88 \pm 0.14$ & $41.13 \pm 5.41$ & $16.52 \pm 2.02$ & $9.00 \pm 0.65$ & $2.02 \pm 0.08$ & $11.36 \pm 0.66$ \\
\hline
\end{tabular}

Figure 1 represents a dendrogram with three clusters of clones and Figure 2 provides the information about plot projection of clones on the basis of assayed nutrients.

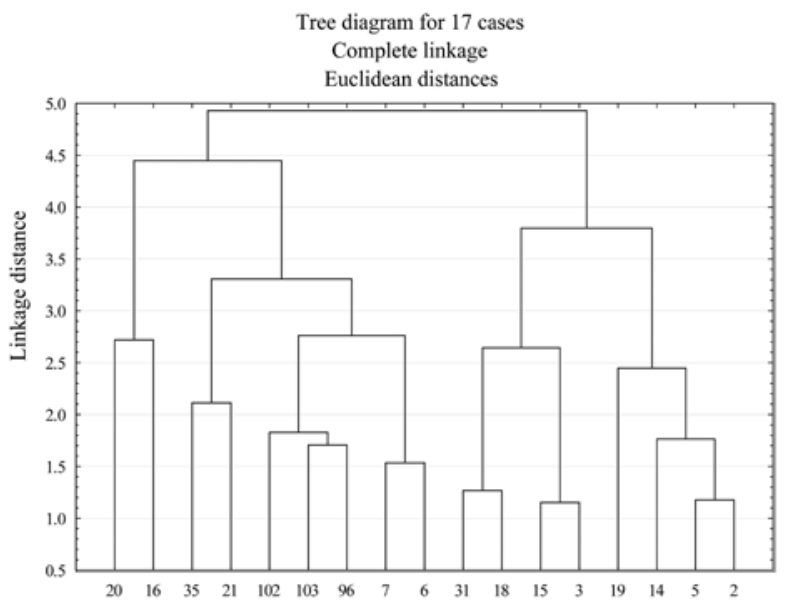

Figure 1. The dendrogram of honeyberry (Lonicera kamtschatica) on the basis of evaluation of anthocyanin content in fresh mass (FM) related to dry matter, sugars, organic acids and ascorbic acid

Distribution of clones into clusters clarifies principal component classification. Factor 1 represented variable correlation of organic acids $(-0.83)$, anthocyanin
$(-0.74)$ and dry matter $(-0.70)$ versus sugars $(0.12)$, factor 2 correlation of organic acids $(-0.25)$ and dry matter $(-0.24)$ versus ascorbic acid (0.71) (Fig. 2).

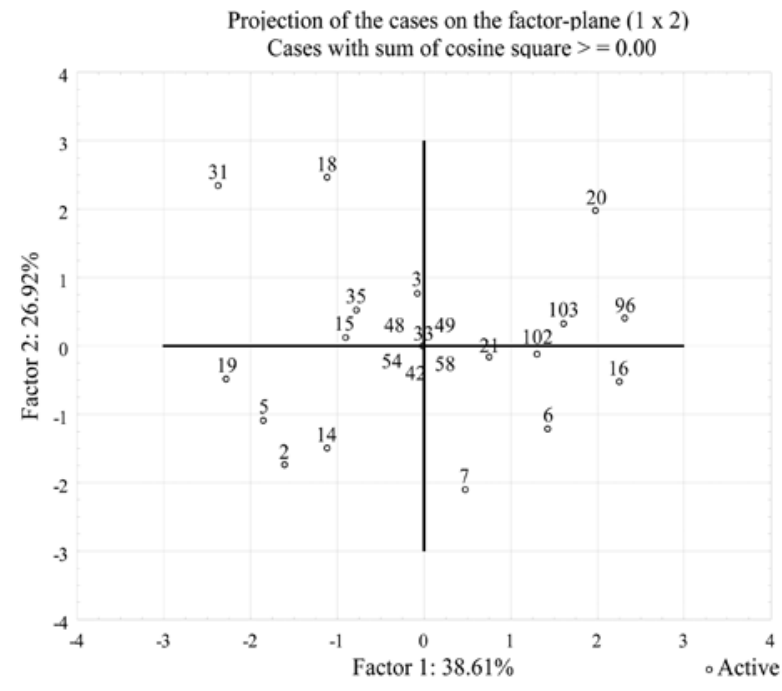

Figure 2. Graph of projection of clones honeyberry (Lonicera kamtschatica) according to factor 1 and 2

Results of analyses are given in Table and tree diagram (Fig. 1). Finally, we obtained three clusters, the first cluster with clones LKL-6, LKL-7, LKL-96, LKL103, LKL-102, LKL-21 and LKL-5, the second cluster 
with clones LKL-3, LKL-15, LKL-18, LKL-31, LKL2, LKL-5, LKL-14 and LKL-19 and the third cluster with clones LKL-16 and LKL-20. Results of principal component analysis showed that LKL-18 and LKL-31 on the left of the graph had high content of organic acids, anthocyanin and dry matter opposite to low content of sugars and vitamin C. LKL-96 and LKL-16 were on the right of the graph thanks to the high content of sugars and low content of organic acids, anthocyanin and dry matter. We found LKL-20 having high content of sugars and ascorbic acid. LKL-2, LKL-5 and LKL-14 had low content of vitamin $\mathrm{C}$ and higher content of organic acids, dry matter and anthocyanin. LKL-7, LKL-6 and LKL-14 had less organic acids and anthocyanin and lower content of vitamin C.

\section{Discussion}

The content of TA in fresh samples of honeyberry clones ranged from $5.96 \mathrm{~g} \mathrm{~kg}^{-1}$ (LKL-103) up to $19.18 \mathrm{~g}$ $\mathrm{kg}^{-1}$ (LKL-18). These values are higher in comparison with a Polish cultivar 'Atut' (2.35 $\left.\mathrm{g} \mathrm{kg}^{-1}\right)$ (Malodobry et al., 2010) and 24 elite hybrids of honeyberry (2.06$5.79 \mathrm{~g} \mathrm{~kg}^{-1}$ ) from Romania (Mladin et al., 2011). The similar results with no statistically significant changes in anthocyanin content in honeyberries during storage at low temperatures on the anthocyanin content were published by Ochmian et al. (2008). Our results are in agreement with those of Lochachoompol et al. (2005) who stored the samples of blueberry frozen at $-20^{\circ} \mathrm{C}$ for three months or Scibiz and Mitek (2007) who studied the effect of long term storage on blueberry samples by freezing. On the contrary, Bryksin et al. (2007) studied 11 Russian cultivars of honeyberry and determined only a decline in TA content ranging from $4.50 \%$ to $61.29 \%$. In the same way, only loss in anthocyanins was observed in sour cherries stored for six months at $-23^{\circ} \mathrm{C}$ (Chaovanalikit, Wrolstad, 2004) or blueberry samples stored by freezing at $-18^{\circ} \mathrm{C}$ for 6 months (Vollmanova et al., 2009).

According to Scibiz and Mitek (2007), an increase in TA content can be caused by the fact that anthocyanins in frozen samples are easier to be extracted, which leads to an increase of their content, which was confirmed in LKL-2, LKL-5 and LKL-6. In agreement with this group of clones, Malodobry et al. (2010) found a $30 \%$ increase in anthocyanin content of the Polish of honeyberry cultivar 'Atut' stored at $-18^{\circ} \mathrm{C}$ for six months. The TA content is constant during freezing process but changes in $\mathrm{pH}$ can cause changes in fruit colour. The all observed differences in TA content can be caused by differences in the studied cultivars, the way of the sample extraction, and the method of TA determination as well as climatic and soil conditions (Jurikova, Matuskovic, 2007; Jurikova et al., 2012).

According to Gazdik et al. (2008), Jurikova and Matuskovic (2007), Jurikova et al. (2012) and Rop et al. (2011), the antioxidant activity of honeyberry fruit was high due to high level of the total flavonoid and total polyphenol content. On the other hand, in our experiment the statistically significant weak negative correlation between anthocyanin content and TAC of fruit $(R=-0.585)$ at $\alpha=0.05$ was proved. We determined the highest value of TAC in LKL-103, contrary to the lowest value of TA. It means that other flavonoids like rutin, quercetin, isoquercetin and hydroxycinnamic acids and their synergic influence mostly contributed to TAC of fruit as it has been proved by studies of Jurikova et al. (2012). Our results agreed with Nawirska et al. (2007) who pointed to a strong negative correlation between TAC and TA. Vollmanova et al. (2009) observed the same negative correlation in blueberry samples. In comparison with anthocyanins, ascorbic acid has only minor effect in antioxidant activity of fruit according to Gazdik et al. (2008), in our experiment the negative correlation between TAA of fruit and ascorbic acid was observed $(R$ $=-0.330$ ).

Generally, the anthocyanin content in honeyberries clones was high and the content of other chemical components was average in comparison with other lesser known fruit species (Gazdik et al., 2008). Our results are in agreement with previous studies of Matuskovic et al. (2009) who confirmed statistically significant influence of organic acids and ascorbic acid on the anthocyanin content.

\section{Conclusion}

The content of anthocyanins in 16 assayed clones of honeyberry (Lonicera kamtschatica) ranged from 5.96 $\mathrm{mg} \mathrm{kg}^{-1}$ (LKL-103) up to $19.18 \mathrm{~g} \mathrm{~kg}^{-1}$ (LKL-18) in fresh samples and $4.88 \mathrm{mg} \mathrm{kg}^{-1}$ (LKL-103) - $15.00 \mathrm{mg} \mathrm{kg}^{-1}$ (LKL-5) in frozen samples. Storage of honeyberry fruit by freezing at $-18^{\circ} \mathrm{C}$ seemed to be very effective for the preservation of anthocyanin content. Anthocyanins displayed interaction with other components of fruit dry matter, organic acids, sugars and ascorbic acid as this was proved by the results of cluster analysis. Positive statistically significant relationship between anthocyanins and TAC of fruit was proved. On the other hand, the relation between anthocyanins and ascorbic acid was negative. Honeyberry represented a very valuable source of natural pigments - anthocyanins which can be widely utilized in food processing and for pharmaceutical or medicinal purposes. In this way, LKL-19, LKL-21 and LKL-31 represented cultivars with the highest values of anthocyanins.

Because of the high sugars and ascorbic acid content, LKL-20 can be recommended for direct consumption.

\section{Acknowledgements}

Author Jiri Sochor would like to express his thanks to CZ.1.07/2.3.00/30.0017 Postdocs in Biological Sciences.

Received 02082013

Accepted 12032014 


\section{References}

Baloghova M., Paulovicsova B., Turianica I. 2009. Biological characteristics of selected berries. Acta Horticulturae et Regiotecturae, 12: 49-52

Beslic Z. S., Todic S. R., Tesevic V. V., Jadranin M. B., Novakovic M. M., Tesic D. 2010. Pruning effect on content of quercetin and catechin in berry skins of $\mathrm{cv}$. Blaufränkisch (Vitis vinifera L.). Turkish Journal of Agriculture and Forestry, 34: 461-466

Bryksin D. M., Bočarova T. E., Gryšutina T. N. 2007. Ocenka kačestva zamorožennych plodov u sortov žimolosti selekcii VIIS im. I. V. Mičurina. Sovremennyje problemy technologii proizvodstva, chranenija, pererabotky i expertizii kačestva sel'skochozjajstvennoj produkcii. Materialy meždunarodnojnaučno-praktičeskoj konferencii, 1: 35-38 (in Russian)

Chaovanalikit A., Wrolstad R. E. 2004. Anthocyanin and polyphenolic composition of fresh and processed cherries. Journal of Food Science, 69: 73-78 http://dx.doi.org/10.1111/j.1365-2621.2004.tb17859.x

Chaovanalikit A., Thompson M. M., Wrolstad R. E. 2004. Characterization and quantification of anthocyanins and polyphenolics in blue honeysuckle (Lonicera caerulea L.). Journal of Agriculture and Food Chemistry, 52: 848-852 http://dx.doi.org/10.1021/jf030509o

Ercisli S., Esitken A. 2004. Fruit characteristics of native rose hip (Rosa spp.) selections from the Erzurum Province of Turkey. New Zealand Journal of Crop and Horticultural Science, 32: 51-53 http://dx.doi.org/10.1080/01140671.2004.9514279

Gazdik Z., Reznicek V., Adam V., Zitka O., Jurikova T., Krska B., Matuskovic J., Plsek J., Saloun J., Horna A., Kizek R. 2008. Use of liquid chromatography with electrochemical detection for the determination of antioxidants in less common fruits. Molecules, 13: 2823-2836

http://dx.doi.org/10.3390/molecules 131102823

Gruia M. I., Oprea E., Gruia I., Negoita V., Farcasanu I. C. 2008. The antioxidant response induced by Lonicera caerulaea berry extracts in animals bearing experimental solid tumors. Molecules, 13: 1195-1206 http://dx.doi.org/10.3390/molecules 13051195

Füleki T., Francis F. J. 1968. Quantitative methode for anthcyane. II. Determination of total antocyanine and degredation index for cranberry juice. Journal of Food Science, 33: 78-83

Jurikova T., Matuskovic J. 2007. The study of irrigation influence on nutritional value of Lonicera kamtschaticacultivar Gerda 25 and Lonicera edulis berries under the Nitra conditions during 2001-2003. Horticultural Science, 34: 1-6 http://dx.doi.org/10.3390/molecules17010061

Jurikova T., Rop O., Mlcek J., Sochor J., Balla S., Szekeres L., Hegedusova A., Hubalek J., Adam V., Kizek R. 2012. Phenolic profile of edible honeysuckle berries (genus Lonicera) and their biological effects. Molecules, 17: 61-79

Kafkas S., Ozgen M., Dogan Y., Ozcan B., Ercisli S., Serce S. 2008. Molecular characterization of mulberry accessions in Turkey by AFLP markers. Journal of the American Society for Horticultural Science, 133 (4): 593-597

Lochachoompol V., Srzednicki G., Crask J. 2005. The change of total anthocyanins in blueberries and their antioxidant effect after drying and freezing. Journal of Biomedicine and Biotechnology, 5: 248-252
Malodobry M., Bienasz M., Dziedzic E. 2010. Evaluation of the yield and some components in the fruit of blue honeysuckle (Lonicera caerulea var. edulis Turcz. ex. Freyn.). Folia Horticulturae, 22: 45-50 http://dx.doi.org/10.2478/fhort-2013-0150

Matuskovic J., Jurikova T., Jurik I., Šimko J., Gazdik Z. 2009. The content of anthocyanins and ascorbic acid in the genofond of 22 clones of Lonicera kamtschatica (Sevast.) Pojark. Gerda 25. Agriculture, 55 (2): 88-94

Milivojevic J. M., Nikolic M. D., Dragisic Maksimovic J. J., Radivojevic D. D. 2011. Generative and fruit quality characteristics of primocane fruiting red raspberry cultivars. Turkish Journal Agriculture and Forestry, 35: 289-296

Mladin P., Mladin G., Oprea E., Rädulescu M., Nicola C. 2011. Variability of anthocyanins and tannins in berries of some Lonicera caerulea var. kamtschatica, Aronia melanocarpa and Berberis thunbergii var. atropurpurea genotypes. Scientific papers, XXVII: $12-18$

Myjavcová R., Marhold P., Křenb V., Šimánek V., Ulrichova J., Palíková I., Papoušková B., Lemr K., Bednáŕ P. 2010. Analysis of anthocyanin pigments in Lonicera (Caerulea) extracts using chromatographic fractionation followed by microcolumn liquid chromatography-mass spectrometry. Journal of Chromatography A, 217 (51): 7392-7941

Nawirska A., Letowska A. S., Kucharska A. Z. 2007. Wlasciwosci przeciwutleniajace wytlokow $\mathrm{z}$ vybranych owocow kolorowych. Zywność Nauka Technologia Jakość, 53: 120-125 (in Polish)

Ochmian I., Grajkowski J., Skupien K. 2008. Field performance, fruit chemical composition and formness under cold storage and stimulated "shelf-life" conditions of tree blue honeysuckle cultigens (Lonicera caerulea). Journal of Fruit and Ornamental Plant Research, 16: 83-91

Parejo L., Codina C., Petrakis C., Kefalas P. 2000. Evaluation of scavenging activity assessed by Co(II)/EDTA-induced luminol chemiluminescence and DPPH center dot (2,2-diphenyl-1-picrylhydrazyl) free radical assay. Journal of Pharmacological and Toxicological Methods, 44: 507512 http://dx.doi.org/10.1016/S1056-8719(01)00110-1

Poledica M. M., Milivojevic J. M., Radivojevic D. D., Dragisic Maksimovic J. J. 2012. Prohexadione-Ca and young cane removal treatments control growth, productivity, and fruit quality of the Willamette raspberry. Turkish Journal Agriculture and Forestry, 36: 680-687

Rop O., Reznicek V., Mlcek J., Jurikova T., Balik J., Sochor J., Kramarova D. 2011. Antioxidant and radical oxygen species scavenging activities of 12 cultivars of blue honeysuckle fruit. Horticultural Science, 38: 63-70

Scibiz I., Mitek M. 2007. The changes of antioxidant properties in highbush blueberries (Vaccinium corymbosum L.) during freezing and long-term frozen storage. Acta Scientiarum Polonorum Technologia Alimentaria, 6: 75-82

Svobodova A., Zdarilova A., Vostalova J. 2009. Lonicera caerulea and Vaccinium myrtillus fruit polyphenols protect $\mathrm{HaCaT}$ keratinocytes against UVB-induced phototoxic stress and DNA damage. Journal of Dermatological Science, 56: 196-204 http://dx.doi.org/10.1016/j.jdermsci.2009.08.004

Vollmanova A., Toth T., Urminska D., Polakova Z., Timoracka M., Margitanova E. 2009. Anthocyanins content in blueberries (Vaccinium corymbosum L.) in relation to freezing duration. Czech Journal of Food Science, 27: 204-206 
ISSN 1392-3196 / e-ISSN 2335-8947

Zemdirbyste-Agriculture, vol. 101, No. 2 (2014), p. 215-220

DOI 10.13080/z-a.2014.101.028

\section{Antocianinụ kiekis sausmedžio (Lonicera kamtschatica) klonuose šaldymo metu, priklausomai nuo antioksidantinès ir maistinės vertės rodikliụ}

T. Jurikova ${ }^{1}$, S. Ercişli ${ }^{2}$, O. Rop ${ }^{3}$, J. Mlcek ${ }^{4}$, S. Balla ${ }^{1}$, R. Zitny ${ }^{1}$, J. Sochor ${ }^{5}$, A. Hegedusova ${ }^{6}$, D. Benedikova ${ }^{7}$

${ }^{1}$ Konstantino Filosofo universiteto Centrinès Europos studijų fakulteto Pedagoginis institutas

${ }^{2}$ Atatürk universitetas, Turkija

${ }^{3}$ Čekijos Respublikos verslo ir viešbučių vadybos kolegija

${ }^{4}$ Tomas Bata universitetas, Čekijos Respublika

${ }^{5}$ Mendel universitetas, Čekijos Respublika

${ }^{6}$ Slovakijos žemès ūkio universitetas

${ }^{7}$ Slovakijos augalininkystès tyrimų centras

\section{Santrauka}

Tyrimo tikslas - taikant klasterinę analizę nustatyti antocianinų kiekio pokyčius septyniolikoje atrinktų Klčov’s sausmedžio (Lonicera kamtschatica (Sevast.) klonų, juos šešis mėnesius šaldant $-18^{\circ} \mathrm{C}$ temperatūroje, ir ryšị tarp antocianinų bei sausųjų medžiagų, cukraus, organinių rūgščių ir askorbino rūgšties kiekio šviežiuose vaisiuose. Sausmedžio klonai pagal sausujų medžiagų, cukraus, organinių rūgščių bei suminị antocianinų kiekị ir bendrają antioksidacinę gebą gali būti sugrupuoti ị tris klasterius. Bendras šviežiuose èminiuose nustatytas antocianinų kiekis buvo 5,96-19,80 mg $100 \mathrm{~g}^{-1}$ žalios masès. Rūgščių 80 \% etanolio ekstraktų slopinamasis poveikis DPPH (1,1-difenil-2-pikrilhidrazi) radikalui svyravo nuo 30,03 iki 41,13\%. Antiocianinai silpnai neigiamai koreliavo su bendraja antioksidacine geba $(R=-0,585)$.

Reikšminiai žodžiai: antiocianinai, antioksidacinė veikla, askorbo rūgštis, Lonicera kamtschatica, sausosios medžiagos, šaldymas. 